\title{
Studies on the Absorption of Radiocalcium from Seawater in Three-line Grant (Parapristipoma trilineatum) in Relation to Dietary Calcium
}

\author{
M. Amzad Hossain \\ Department of Fisheries, Bangabandhu Sheikh Mujibur Rahman Agricultural University \\ Gazipur 1706, Bangladesh, E-mail: m_amzad_hossain@hotmail.com
}

\begin{abstract}
A study was conducted to know the absorption of ${ }^{45} \mathrm{Ca}$ from seawater in three-line grant in presence of dietary Ca. Juveniles of three-line grant were fed diets with calcium (Ca) supplement from Ca-lactate or without $\mathrm{Ca}$ supplement for 2 weeks, then exposed to seawater containing ${ }^{45} \mathrm{CaCl}_{2}$. Overall ${ }^{45} \mathrm{Ca}$ absorption from seawater was higher in this species. Absorption rate was rapid initially and become slow with the increase in exposure time. After 23 hours exposure, absorption of ${ }^{45} \mathrm{Ca}$ was higher in fish fed a diet without $\mathrm{Ca}$ supplement compared those fed with $\mathrm{Ca}$ supplement. It was found that in threeline grant $\mathrm{Ca}$ absorption from seawater increased in cases where dietary $\mathrm{Ca}$ supplement was lacking. Therefore, dietary Ca supplementation may be dispensable for this species.
\end{abstract}

Keywords: Three-line grant, calcium, absorption, seawater

\section{Introduction}

Calcium $(\mathrm{Ca})$ is an important nutrient for fish. It has been generally accepted that fish can absorb $\mathrm{Ca}$ from surrounding water (Templeton and Brown, 1963; Love, 1980; Ichii and Mugiya, 1983) and a dietary Ca supplement may not be necessary if the rearing water contained adequate Ca (Ogino and Takeda, 1976, 1978; Shim and Ho 1989). However, although seawater contains a large amount of dissolved $\mathrm{Ca}$, it was observed in some previous studies that requirements of dietary $\mathrm{Ca}$ supplement were different among marine fishes (Hossain and Furuichi, 1999a,b, 2000a,b). Findings of the above authors indicate that $\mathrm{Ca}$ absorption capacity from seawater may be different among marine fishes and it is necessary to investigate the absorption of calcium from seawater and the interaction between dietary and environmental $\mathrm{Ca}$ in marine fishes. Radiotracer techniques are a suitable device to study the absorption of $\mathrm{Ca}$ from seawater.

A number of reports are available on the absorption of ${ }^{45} \mathrm{Ca}$ from surrounding water in freshwater fishes. Most of those studies were mainly concerned with the absorption route of ${ }^{45} \mathrm{Ca}$ and its distribution to different body parts. $\mathrm{Ca}^{2+}$ absorption is active in freshwater and MR (mitrochondria rich) or chlorides cell are the sites of active uptake on the gill (Payan et al., 1981; Ishihara and Mugiya, 1987; Perry and Flick, 1988; Flick et al., 1995). In addition to gills, significant $\mathrm{Ca}^{2+}$ uptake may also occur through the general body surface i.e. skin and fins (Dacke, 1979). A $\mathrm{Ca}^{2+}$ uptake model in freshwater indicated that the $\mathrm{Ca}^{2+}$ entered the chloride cells from the water by passive diffusion through $\mathrm{Ca}^{2+}$-selective channels on the apical membrane (Flick and Perry, 1989). These channels may be regulated by agents such as hypocalcin, which could limit the rate of $\mathrm{Ca}^{2+}$ transport. In contrast to freshwater, there are very few reports available on the mechanism of $\mathrm{Ca}$ absorption in marine fishes. Especially the effects of dietary $\mathrm{Ca}$ on the absorption of $\mathrm{Ca}$ from seawater are not widely reported. Reports on the relationship between dietary $\mathrm{Ca}$ and environmental $\mathrm{Ca}$ absorption in three-line grant are scarcely available. 
Three-line grant is a warm water fish species and distributed to southern Japan and China sea. This species dwells in the deeper bottom along the shore where the vegetation is rich and is found swimming all the time around the sea-weeds during the day. The adult fish feed on crustaceans, worms and other small animals. Studies on the nutritional requirements of this species are not widely conducted. In view of the above, attempts were made to determine the absorption of ${ }^{45} \mathrm{Ca}$ from seawater and its relations with dietary $\mathrm{Ca}$ in three-line grant to verify whether dietary $\mathrm{Ca}$ affects $\mathrm{Ca}$ uptake from seawater in this species.

\section{Materials and Methods}

\subsection{Rearing experiment}

Juvenile three-line grant (Parapristipoma trilineatum) produced in the Fishery Research Laboratory of Kyushu University, Japan were acclimatized to indoor tank conditions in a $200-\mathrm{L}$ polycarbonate tank and were fed with experimental diet 1 . After 2 -week acclimatization, the fish were weighed individually and distributed to $30-\mathrm{L}$ polycarbonate tanks (45 fish in each tank, average weight $1.8 \mathrm{~g}$, three tanks for each treatment). Tanks were provided with continuous sand-filtered seawater and medium strong air supply and cleaned everyday before the morning feeding. Fish were reared for 14 days on the experimental diets 1 and 2. Diets were supplied upto satiation level twice a day for 2 weeks until fish were subjected to the radioisotope experiment.

\subsection{Experimental diet}

Two experimental diets were prepared with and without Ca supplementation (Table 1). Casein (vitamin free, $200 \mathrm{mg} \mathrm{Ca} / \mathrm{kg}$ ) and a pollack liver oil were used as protein and lipid source, respectively. A small amount (10\% of diet) of squid meal (600 mg Ca/kg) was added to the diet as protein source, because casein is less acceptable to three-line grant. Both the diets contained a vitamin mixture and a $\mathrm{Ca}$ free mineral mixture. Diet 1 was supplied with $\mathrm{Ca}$ - lactate to provide $0.5 \% \mathrm{Ca}$ and Diet 2 was without a $\mathrm{Ca}$ supplement. All the ingredients were mixed properly with an aliquot of water and pellated in a laboratory type pellet machine. The diets were cut into $2 \mathrm{~mm}$ size, dried for 40 min at $60^{\circ} \mathrm{C}$, and stored at $-20^{\circ} \mathrm{C}$ until fed. The proximate and mineral compositions of the experimental diets are shown in Table 2.

\subsection{Absorption of radioactive $\mathrm{Ca}$}

On the final day of rearing, after $1 \mathrm{~h}$ of morning feeding, the fish were transferred to 5 -L beakers containing 3-L of seawater (15 fish per beaker, three beakers for each treatment). Seawater in the beaker contained ${ }^{45} \mathrm{Ca}$ (as calcium chloride in water, half life 163 days), a product of New life Science Product, USA supplied by Daiichi Pure Chemicals, Japan. Calculated radioactivity of the rearing seawater was $1.67 \mathrm{mBq} / \mathrm{L}$ seawater. Beakers were placed side by side in a constant temperature room $\left(26^{\circ} \mathrm{C}\right)$, provided with moderate aeration and covered with filter paper to prevent any possible scattering of water.

\subsection{Sampling}

Seawater samples ( $1 \mathrm{ml}$ in triplicate) were taken to monitor the radioactivity at $0,1,4$ and $23 \mathrm{~h}$ after transfer of fish to the radioactive seawater. After 1,4 and $23 \mathrm{~h}$ of transfer of fish to the beakers $(2,5$ and $24 \mathrm{~h}$ of last feeding, respectively), 5 fish were sampled from each beaker and were kept in normal seawater for a few minutes, then the fish were killed with MS222 in another beaker containing deionised water and were rinsed well to remove adhering ${ }^{45} \mathrm{Ca}$. Fish were blotted with a tissue paper and the whole body weights were measured. Digestive tracts were removed from the whole carcasses to minimize the contaminated radioactive ${ }^{45} \mathrm{Ca}$, which might have been introduced through the feces or seawater contents in the digestive tract. Then, all the carcass samples were preserved individually in small labelled polyethylene bags and stored at $-20^{\circ} \mathrm{C}$ for digestion. 
Table 1. Experimental diets for three-line grant with Ca supplement and without Ca supplement

\begin{tabular}{lcc}
\hline \multicolumn{1}{c}{ Ingredient $(\%)$} & \multicolumn{2}{c}{ Diet No. } \\
\cline { 2 - 3 } & 1 (With Ca) & 2 (Without Ca) \\
\hline Casein & 45.0 & 45.0 \\
Squid meal & 10.0 & 10.0 \\
Alpha-starch & 5.0 & 5.0 \\
Dextrin & 10.0 & 10.0 \\
Pollack liver oil & 10.0 & 10.0 \\
Vitamin mix. $^{* 1}$ & 3.0 & 3.0 \\
Mineral mix. $^{* 2}$ & 4.5 & 4.5 \\
Guar gum $_{\text {Feeding stimulant }}{ }^{* 3}$ & 3.0 & 3.0 \\
Ca-lactate & 1.5 & 1.5 \\
Alpha-cellulose & 3.8 & - \\
\hline
\end{tabular}

${ }^{*}{ }^{1}$ Vitamin mixture (mg/kg diet): Thiamine- $\mathrm{HCl}, 60$; riboflabin, 200; pyridoxine- $\mathrm{HCl} 40$; vitamin $\mathrm{B}_{12}, 0.09$; nicotinic acid, 800; Ca pantothenate, 280; inositol, 4000; biotin, 6; folic acid, 15; PABA, 4000; choline chloride, 8000; ascorbic acid, 2000; alpha-tocopherol, 400; menadione, 40; beta-carotene, 12; vitamin $\mathrm{D}_{3}, 0.05$.

$*^{2}$ Mineral mixture (mg/kg diet): $\mathrm{KCl} 3840 ; \mathrm{MgSO}_{4} \cdot 5 \mathrm{H}_{2} \mathrm{O} 4080 ; \mathrm{NaH}_{2} \mathrm{PO}_{4} \cdot 2 \mathrm{H}_{2} \mathrm{O}, 34,260 ;$ Fe-citrate, 1200 ; $\mathrm{AlCl}_{3} .6 \mathrm{H}_{2} 0,45 ; \mathrm{CuCl}, 7.9 ; \mathrm{KI}, 1.9 ; \mathrm{CoCl}_{2} \cdot 6 \mathrm{H}_{2} \mathrm{O}, 0.7$.

*3 Feeding stimulant g/kg diet (Takaoka et al., 1995): Alanine 1.3, Aspertate.Na, 0.21, betaine 6.79; glycine 3.29; serine 0.24.

Table 2. Proximate and mineral compositions of the experimental diets for three-line grant

\begin{tabular}{lcc}
\hline \multicolumn{1}{c}{ Ingredient $(\%)$} & \multicolumn{2}{c}{ Diet no. } \\
\cline { 2 - 3 } & 1 (With Ca) & 2 (Without Ca) \\
\hline Proximate composition & 17.0 & 16.2 \\
Moisture $(\%)$ & 50.1 & 51.1 \\
Crude protein $(\% \mathrm{dm}) *^{1}$ & 10.8 & 10.9 \\
Crude lipid $(\% \mathrm{dm})$ & 5.5 & 4.7 \\
Crude ash $(\% \mathrm{dm})$ & & \\
Mineral composition & 0.55 & 0.02 \\
$\mathrm{Ca}(\%)$ & 1.00 & 1.02 \\
$\mathrm{P}(\%)$ & 385 & 390 \\
$\mathrm{Mg}(\mu \mathrm{g} / \mathrm{g})$ & 260 & 255 \\
$\mathrm{Fe}(\mu \mathrm{g} / \mathrm{g})$ & 40.2 & 40.5 \\
$\mathrm{Zn}(\mu \mathrm{g} / \mathrm{g})$ & 22.4 & 23.0 \\
$\mathrm{Mn}(\mu \mathrm{g} / \mathrm{g})$ & 10.2 & 12.4 \\
$\mathrm{Cu}(\mu \mathrm{g} / \mathrm{g})$ & &
\end{tabular}

$$
{ }^{71} \mathrm{dm}=\text { dry matter. }
$$

\subsection{Digestion of samples}

Carcass samples were digested with a mixture of nitric acid-perchloric acid. For this, samples were defrosted at room temperature and each carcass was taken in a $50 \mathrm{ml}$ beaker containing 5 $\mathrm{ml}$ concentrated nitric acid and was kept overnight. Then it was heated over a hot plate until it became less than $1 \mathrm{ml}$. Then $5 \mathrm{ml}$ concentrated nitric acid and $4 \mathrm{ml}$ perchloric acid (70\%) were added and heated further to become less than $1 \mathrm{ml}$. In that concentrated sample, two $\mathrm{ml}$ deionised water was added and heated for 15 minutes. The digested samples were cooled and diluted to $25 \mathrm{ml}$ with deionised water. 


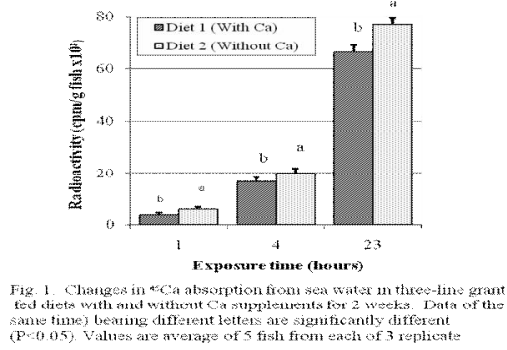

2.6. Counting of radioactivity and statistical analysis

An amount of $1 \mathrm{ml}$ digested sample was taken in a $5 \mathrm{ml}$ vial, then $4 \mathrm{ml}$ scintillator [ACS-II (aqueous counting scintillant) containing a mixture of aromatic hydrocarbons-glycol ethers (Amersham, USA)] was added and mixed well. Similarly, scintillator also was added directly to the untreated seawater. The radioactivity of ${ }^{45} \mathrm{Ca}$ in the digested samples and seawater, taken in $5 \mathrm{ml}$ vial, was measured using a liquid scintillation counter (Aloka 3000, Aloka, Japan). Student ' $T$ ' test $(P<0.05)$ were used for data analysis.

\section{Results and Discussion}

The number of fish used in the present experiments did not affect the ${ }^{45} \mathrm{Ca}$ concentration in seawater during the experiments which was around $10 \times 10^{4}$ $\mathrm{cpm} / \mathrm{ml}$ seawater. The influences of physiochemical decay of isotope and evaporation of seawater which might have caused the increase in the concentration of the radioisotope in water during the experimental period were considered negligible. Absorptions of ${ }^{45} \mathrm{Ca}$ in three-line grant are shown in Fig. 1. At the initial stage absorption of ${ }^{45} \mathrm{Ca}$ was high in Diet 2 without Ca supplement than in diet 1 with $\mathrm{Ca}$ supplement. Similar trend

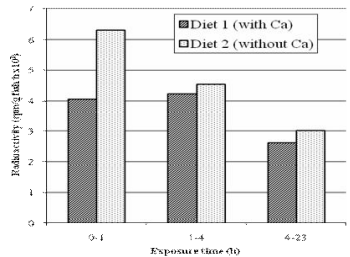

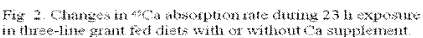

was found from the $4^{\text {th }} \mathrm{h}$ of exposure to radioactive seawater. At the end of $23 \mathrm{~h}$ exposure, lacking of Ca supplement to the diet enhanced the absorption of ${ }^{45} \mathrm{Ca}$, in other word, three-line grant decreased its ${ }^{45} \mathrm{Ca}$ absorption from seawater when $\mathrm{Ca}$ was available from the diet. It was observed in some previous studies that a dietary $\mathrm{Ca}$ supplement decreased the ${ }^{45} \mathrm{Ca}$ absorption from environmental water in redlip mullet, red sea bream and black sea bream (Hossain, 2000). Overall ${ }^{45} \mathrm{Ca}$ absorption was high in Three-line grant in the present study, which was $66-77 \times 10^{3} \mathrm{cpm} / \mathrm{g}$ wet weight in all the treatments after $23 \mathrm{~h}$ exposure (Fig. 1). The overall absorption was $89-129 \times 10^{3} \mathrm{cpm} / \mathrm{g}$ wet weight, 83$93 \times 10^{3} \mathrm{cpm} / \mathrm{g}$ wet weight, $18-20 \times 10^{3} \mathrm{cpm} / \mathrm{g}$ wet weight and $38-39 \times 10^{3} \mathrm{cpm} / \mathrm{g}$ wet weight in red sea bream, black sea bream, redlip mullet and girella, respectively (Hossain 2000). He further observed that absorption of ${ }^{45} \mathrm{Ca}$ was very high in red sea bream and black sea bream. Dietary Ca supplement was not necessary for red sea bream and black sea bream (Hossain and Furuichi, 1999a,b).

The absorption rate $(\mathrm{cpm} / \mathrm{g}$ fish/h during the time intervals of $0-1,1-4$ and $4-23 \mathrm{~h}$ of exposure to ${ }^{45} \mathrm{Ca}$ ) was rapid initially and slowed down with the increase of exposure time in both the treatments (Fig. 2). Studies utilizing radioisotopes have 
indicated the fact that the bone-seeking elements, $\mathrm{Ca}$ and strontium, are directly taken up from environmental water by marine fishes as well as freshwater fishes (Boroughs et al., 1957). Hossain (2000) reported that the ${ }^{45} \mathrm{Ca}$ absorption increased when $\mathrm{Ca}$ was not supplied to the diet in case of red sea bream, black sea bream and girella. Absorption of ${ }^{45} \mathrm{Ca}$ was similarly high in three-line grant when fed a diet without Ca supplement. Ichii and Mugiya (1983) found the presence of a compensatory action in $\mathrm{Ca}$ uptake between dietary and environmental $\mathrm{Ca}$, where the $\mathrm{Ca}$ uptake in goldfish (Carassius auratus) was stimulated by a deficiency in dietary Ca supplement. In that study gold fish fed with a Ca-deficient diet showed 18\% higher an uptake of environmental $\mathrm{Ca}$ than that of the control. This agrees with the findings of the present study, where three-line grant was found to increase $\mathrm{Ca}$ absorption from seawater when fed a diet without $\mathrm{Ca}$ supplement compared to a diet with $\mathrm{Ca}$ supplement, which indicates that dietary $\mathrm{Ca}$ supplement may be dispensable for the experimental species. On the other hand, both dietary and environmental $\mathrm{Ca}$ also were necessary for normal calcification of regenerating scales of tilapia (Oreochromis niloticus) (Takagi and Yamada, 1992) and for maintaining of health in channel catfish swim-up fry (Ictalurus punctatus) (Scarpa and Gatlin, 1993). However, the mechanisms of $\mathrm{Ca}$ balance between environmental and dietary $\mathrm{Ca}$ in marine fishes are yet to be well understood.

In the present study the ${ }^{45} \mathrm{Ca}$ absorption rate was high initially and decreased as the exposure time increased. It was observed in both the treatments that the intestine was full with ingesta at $1 \mathrm{~h}$, with little or no ingesta at $4 \mathrm{~h}$ and was completely empty at $23 \mathrm{~h}$. The results suggests that although threeline grant always absorb $\mathrm{Ca}$ from seawater, the absorption of $\mathrm{Ca}$ increases with ingestion of a diet and decreases with excretion of ingesta.

\section{Conclusions}

It may be concluded that three-line grant increased $\mathrm{Ca}$ absorption from seawater when dietary $\mathrm{Ca}$ is not available. Therefore, a dietary $\mathrm{Ca}$ supplement may be dispensable for this species. However, the present findings must be confirmed through further rearing experiments. Besides, important marine fishes need to be tested for $\mathrm{Ca}$ absorption capacity from seawater.

\section{References}

Boroughs, H., Townsley, S.J. and Hiatt, R.W. 1957. The metabolism of radionuclitides by marine organisms. III. The uptake of calcium $^{45}$ in solution by marine fish. Limnology and Oceanography, 2: 28-32.

Dacke, G.G. 1979. Calcium Regulation in Submammalian Vertebrate. Academic Press, New York, p 346.

Flick, G. and Perry, S.F. 1989. Cortisol stimulates whole body calcium uptake and branchial calcium pump in freshwater rainbow trout. Journal of Endocrinology, 120: 75-82.

Flick, G., Verbost, P.M. and Wendelaar Bonga, S.E. 1995. Calcium transport processes in fishes. In: Cellular and Molecular Approaches to Fish Ionic Regulation. Fish physiology. Vol. 14, Wood, C.M. and Shuttleworth, T.L. (eds). Academic Press, San Diego. pp 234-290.

Hossain, M.A. 2000. Studies on the Calcium Nutrition in Marine Fishes. Ph.D Thesis, Kyushu University, Japan. P. 265.

Hossain, M.A. and Furuichi, M. 1999a. Effect of deletion of calcium supplement from purified diet on growth and bone mineralization in red sea bream. Journal Faculty of Agriculture, Kyushu University, 44: 91-97.

Hossain, M.A. and Furuichi, M. 1999b. Necessary of dietary calcium supplement in black sea bream. Fisheries Science, 65: 893-897.

Hossain, M.A. and Furuichi, M. 2000a. Essentiality of dietary calcium supplement in fingerling scorpion fish (Sebastiscus marmoratus). Aquaculture, 189: 155-163.

Hossain, M.A. and Furuichi, M. 2000b. Essentiality of dietary calcium supplement in redlip mullet Liza haematocheila. Aquaculture Nutrition, 6: 33-38.

Ichii, T. and Mugiya, Y. 1983. Effects of dietary deficiency in calcium on growth and calcium 
uptake from aquatic environment in the gold fish, Carrassius auratus. Comperative Biochemistry and Physiology, 74A: 259-263.

Ishihara, A. and Mugiya, Y. 1987. Ultrastructural evidence of calcium uptake by chloride cells in the gills of goldfish Carassius aureus. Journal of Experimental Zoology, 242: 218129.

Love, R.M. 1980. The Chemical Biology of Fishes. Academic Press, New York. P. 286.

Ogino, C. and Takeda, H. 1976. Mineral requirements in fish-III. Calcium and phosphorus requirements in carp. Bulletin of Japanese Society for Scientific Fisheries, 42: 793-799.

Ogino, C. and Takeda, H. 1978. Requirements of rainbow trout for dietary calcium and phosphorus. Bulletin of Japanese Society for Scientific Fisheries, 44: 1019-1022.

Payan, P., Mayer-Gostan, N. and Pang, P.K.T. 1981. Site of calcium uptake in the freshwater trout gill. Journal of Experimental Zoology, 216: 345-347.

Perry, S.F. and Flick, G. 1988. Characterization of branchial transepithelial calcium fluxes in the freshwater trout (Salmo gairdneri). American Journal of Physiology, 254: R491-R498.

Scarpa, J. and Gatlin III, D.M. 1993. Responses of channel catfish (Ictalurus punctatus) swimup fry to dietary calcium in soft and hard water. Comperative Biochemistry and Physiology, 106A: 803-808.

Shim, K.F. and Ho, C.S. 1989. Calcium and phosphorus requirements of guppy Poecilia reticulata. Nippon Suisan Gakkaishi, 55: 1947-1953.

Takagi, Y. and Yamada, J. 1992. Effects of calcium deprivation on the metabolism of acelullar bone in tilapia, Oreochromis niloticus. Comperative Biochemistry and Physiology, 102A: 481-485.

Takaoka, O., Takii, K., Nakamura, M. Kumai, H. and Takeda, M. 1995. Identification of the feeding stimulants for tiger puffer. Fisheries Science, 61(5): 833-836.

Templeton, W.L. and Brown, V.M. 1963. Accumulation of calcium and strontium by brown trout from waters in the United Kingdom. Nature, 198: 198-200. 